\title{
洪水時における砂堆の発達にともなう浮遊砂濃度の変化 \\ Effect of dune development on sediment suspension under unsteady flow conditions
}

\begin{tabular}{lll} 
筑波大学水理実験センター & \multicolumn{2}{l}{ 伊勢屋ふじこ } \\
筑波大学水理実験センター & 正員 & 池 田
\end{tabular}

1. はじめに

出水時に浮遊土砂濃度のピークが流量のピークと一致しないてとが、多数の河川で観測されている。しか し、従来の観測データでは、浮遊土砂を河床物質中から浮遊した狭義の浮遊砂（以下では、てれを単に浮遊 砂と呼ぶ）と、流域の地表面から直接流水中に供給されたウォシュ・ロードとに分けて、それぞれの変化に ついて調べた事例は少ない。そのため、出水時における浮遊砂濃度の変化については、ほとんど知られてい

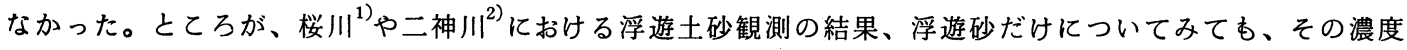
(または流出量) のピークが流量のピークより先に生じているてとが明らかになった。本研究の目的は、砂 床河川において浮遊砂濃度がなぜ増水期に高いのかを解明するてとにある。

浮遊土砂は、ある粒径值で機械的にウォシュ・ロードと浮遊砂に分離させることはできない性質のあので ある。しかし本研究では、4 $\phi(0.063 \mathrm{~mm})$ で便宜的に分けて、シルト・粘土はウォシュ・ロードとして考 察の対象からはずした。その理由は、シルト・粘土の濃度は時間的にもまた空間的にも 1 つのRunの中では 変動しなかったためである。

\section{2. 実験条件の選定亡測定方法}

筑波大学水理実験センターにある大型水路（幅 $4 \mathrm{~m}$ 、長さ $160 \mathrm{~m}$ ) を使った水路実験によって、上記の問 題を検討した。なお、実験結果の詳細はすでに述べた ${ }^{3)}$ 。砂床河川では一般に、低水時には河床表面はかなり 平坦にならされていて、洪水になると砂堆が生じていると考えられる。たとえば、北海道の天塩川における 観測によれば）、低水時には砂床区間のほとんどで河床はかなり平坦化されていた。とてろが、融雪出水時に は砂堆が生じていた。洪水時における砂堆は、石狩川 ${ }^{5)}$ や江戸川 ${ }^{6)}$ をばめとする諸河川であ従来観測されて いる。そこで、実験ではてのような野外の河川の条件を積極的に取り込んだ。すなわち、初期河床を平坦と し、砂堆が形成される流量と勾配の条件を選定し、流量変化を与えた場合 (Case 1) と、流量・勾配を一定 にした場合 (Case 2) という2つのCaseを行った。底質には細礫を含む混合砂（中央粒径 $=0.57 \mathrm{~mm} 、$ 粗砂・ 中砂が70\%を占める) を使用した。下流端から流出した砂砅は掻き上げられて、ベルト・コンベャーで上流 端に返送され、水路内に再び投入されるという循環方式を採用したため、1つの Runを通じて平均の河床高 は安定していた。

物質の運搬と河床形、および流れは密接に相互に関連しあって変化している。そてで、本研究では浮遊運 搬はもとより、河床形と流水の乱れの変化ああわせて計測した。浮遊砂の採取と流水の乱れの測定は、水路 中央の定位置に固定した観測台車を使って行い、台車に付属したトラバーサーの先に测器を取りつけた。浮 遊砂は、上下 3 高度に取りつけた採水口からサイフォン方式で吸引した。吸引速度は平均流速にほぼ等しい ように調整し、一回につき各高度からそれぞれ約 $8 \ell$ を採水した。流水の乱れは三次元型の超音波流速計 （海上電気、Model FC、スパン長 $7.5 \mathrm{~cm}$ )で計測し、M T に収録して計算機処理した。通水すると、測定地 点での砂床面の高さは時々刻々変化する。砂面高の変化は砂面計で、また水位の変化はサーボ式の水位計で 連続的に測定した。一方河床形の変化は、Case 1ではガラス張りの水路側壁区間の一部で、砂床の断面形状 を 2 〜 分抢きにトレースして調べた。またCase 2では、通水途中で停水しては音響湘深と平面写真の撮影 を行って調べた。その際には、水路下流端のゲートを閉じてダムアップし、水面勾配を緩くして停水すると いう操作によって、河床形を通水時の状態のまま保存して計測した。 


\section{Case 1 の結果—不定流下における、浮遊砂濃度の変化におよぼす砂堆の発達・変形の影響}

Case 1 では、流量を $0.4 \sim 1.5 \mathrm{~m}^{3} / \mathrm{sec}$ までの範囲で図－1 B に示すようになめらかに变化させだ。下流 端の堰高を一定に保ったため、水面勾配は図－1 A のよに変動したが、このような水面勾配の変化は、砂 床河川の洪水でもしばしば観測される。図ー $1 \mathrm{C}$ は、浮遊砂濃度の時間的な変化を各採水高度別に示したも のである。浮遊砂の濃度は通水後約 $1 \sim 2$ 時間の間で極めて高いてと、それ以後は濃度が小さく、しかあほ とんど時間的に変化しないてとが一見してわかる。すなわち、浮遊砂濃度の変化が流量変化に対応しないで、 流量の急増する増水期に高いという野外での観測結果が、Case 1 によって実験的に検証された。

このような浮遊砂濃度の時間的な変化は、河床に形成される砂堆の発達と変形が強く関与して生じている。 図一 $1 \mathrm{E}$ に、砂堆の前縁位置の走時曲線と波高の変化を示す。また図-1 $\mathrm{F}, \mathrm{G}, \mathrm{H}$ は、乙の走時曲線をむとにし て、砂堆の平均波長・波高および移動速度を算定して表したあのである。砂堆の発達・変形は、図一 $1 \mathrm{E}$ 示す 4 領域に区分できる。流量の少ないI の時期（小規模な砂堆の形成期）には、平滑な砂床上に波長・波 高の小さい砂堆(砂連と砂堆の区別はいまだ解決されない問題であり、こてでは一括して砂堆と呼ぶ)が生じる。 これらの砂堆は、流下途中で消滅 するむのああるが、追いつき・合 体を繰り返して波長や波高を増大 させる。II の時期（波長・波高の 増大期 ) は、砂堆の波長・波高が とあに急増する時期で、それと同 時に砂堆は $10 \mathrm{~cm} / \mathrm{min}$ 前後の速度 で下流に勢いよく流下する。乙の 時期が丁度増水期にあたる。

それに対して、減水が始まった III の時期（波長の伸長期）には、 波長はなおも増大するものの、砂 堆のトラフが埋められて波高は次 第に減少する傾向にある。移動速 度は遅くなる。 $\mathrm{N}$ の時期 (砂堆上 での小規模な砂堆発生期）には、 大きい砂堆は動きが止まってほと んど変形も移動もしなくなり、代 わっててれらの砂堆の背面上に、

I の時期に作られた砂堆とほぼ同 じ大きさの小規模な砂堆が生じて くる。てうして河床はだんだん平 坦化されていく。

これらの図は、砂堆の形状と流 量変化との間に、時間的なずれ (TIME LAG)があることを示して いる。河床形と流量変化との間の ずれは水路実験 ${ }^{7)}$ にってあ、ま た外国の諸河川 ${ }^{8)}$ であ広く知られ ている。本実験でみられた砂堆の

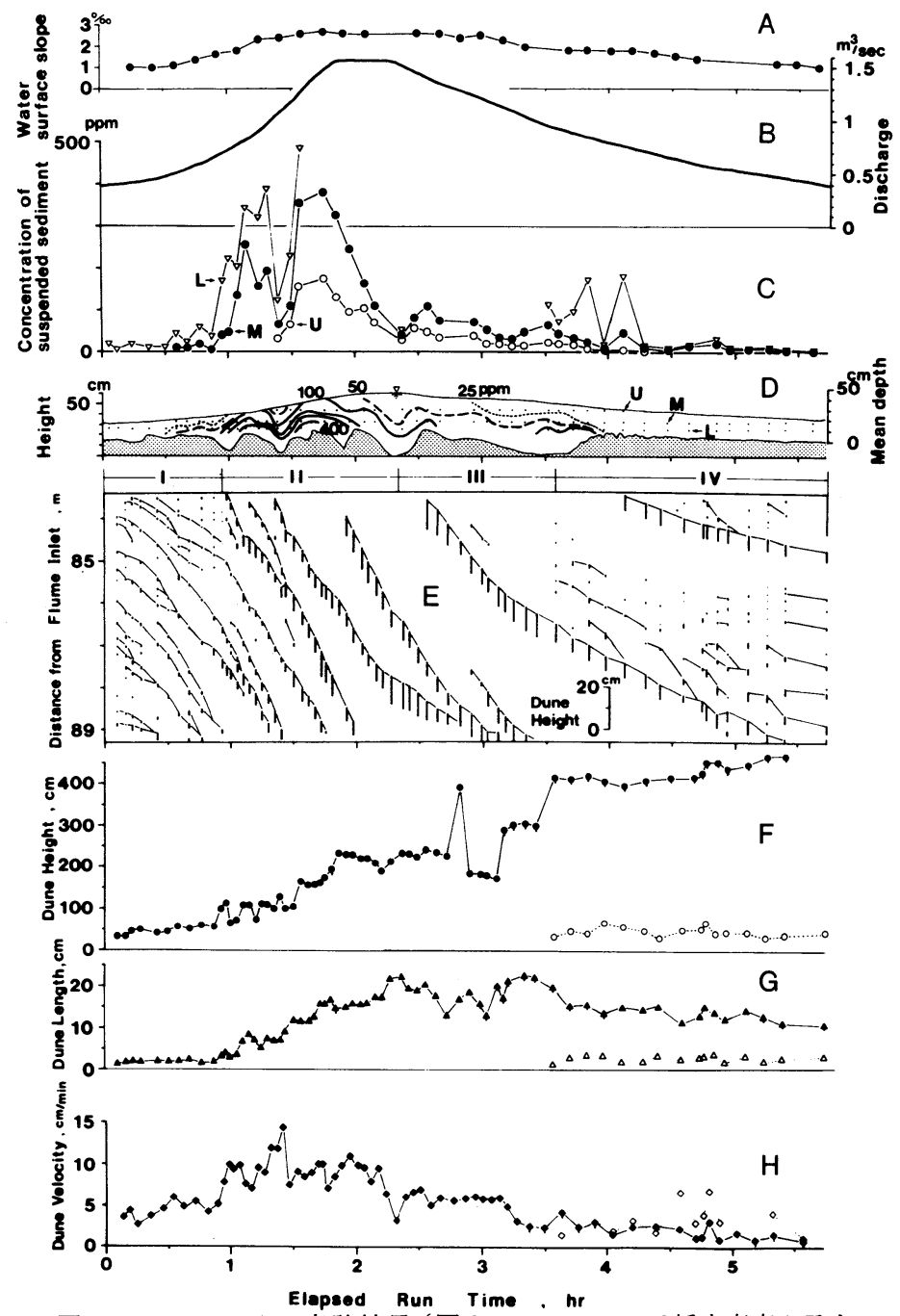

図ー1 Case 1 の実験結果 (図 C, Dの L, M, Uは採水高度を示す。 図 $F, G, H$ の白抜きの点は砂堆の背上の小砂堆の平均値を示す。) 
波長・波高の変化特性は、桜川での河床形の測深結果 ${ }^{9)}$ にっても支持される。

砂堆の形状が活発に成長する増水期に浮遊砂濃度が高いという両者の密接な関係は、さらに、図ー $1 \mathrm{D}$ 亿 あ明瞭に現れている。採水地点での砂床高度は、通水直後はほとんど変化しない。とてろが、通水後 55 分頃 を境にして河床面が低下を始めている。てれは、砂床表面が著しく洗掘されて、砂堆の波高が急激に増加し 始めたてとを意味する。乙てから 2 時間半までの区間で、砂床面の高さは上下に大きく変動しているが、て れは、採水地点を砂堆が次々に流下しているとと、すなわち、砂床高度の高い時が採水地点は砂堆の背面上 にあたり、低い時が砂堆のトラフ上にあたったてとを示す。砂床面の洗掘が始まるまさにその時に、水流中 の浮遊砂濃度が急増していること、砂堆が次々に流下している時に浮遊砂濃度が高いてとがこれによってす 明らかである。その上、浮遊砂濃度が高いての時期には、濃度のアイソプレスに示されるように、浮遊砂濃 度は砂堆の形状に対応した空間的な分布を見せる。つまり図一 1 Cにおいて、浮遊砂濃度は 2 つの山を持っ て增減しているが、てれは、砂堆の背面上で浮遊砂の濃度が高く、トラフ上で濃度が小さいという傾向に起 因する変化である。

\section{Case 2 の結果 一砂堆の発達期に高い浮遊砂濃度}

Case 1 の実験では、流量が変化したてとに加えて水面勾配まであ変動した。1つのRunにおいて水理条 件そのあのが大きく変動したわけであるから、砂堆の発達・変形が浮遊砂濃度に特に強く影響しているとは 必ずしもいえない。そてで、流量と勾配を一定に保ったCase 2 の実験によって、砂堆の発達が浮遊砂の濃 度に与える影響について検討した。実験は、勾配が $1 / 400$ と $1 / 1000$ という条件下で、流量をそれぞれ 0.5 ，

$1.0,1.5 \mathrm{~m}^{3} / \mathrm{sec}$ という3 通りに变えて計 6 Runを実施した。各Runの再現性は、追試を行って確認した。

図一2 は、砂堆が成長する過程の一例である。通水直後に生じた直線的な前縁を持つ二次元的な河床波は、 次第に波長・波高の大きい三次元的な砂堆に成長していく。図-3 Aは、砂堆の波長の時間的な変化を各Run についてプロットした図である。平均波長は、水路内を縦にほぼ 3 分割するような 2 本の綐断測線に沿って 測深した記録から求めた。砂堆の波長は、時間の経過ととあに長くなり、ある時間を経過するとほぼ安定す る。そこでてのような砂堆の波長の時間的な変化から、砂堆の成長過程を 2 つの時期に分ける。つまり、砂 堆の波長が增加する前半の時期を、“砂堆の発達期”とし、波 長が一定してからのちを、“砂堆の安定期”と呼ぶことにする。 そして、形状が定常になるまでにかかる時間を“安定化時間” と名付ける。各Runについて安定化時間を矢印で示した。一方、 砂堆の波高の時間的な变化は、波長の変化ときわめて協和的で ある(図-3 B )。砂堆の波高と波長の比をみると（図一 3 C )、 通水直後を除いては各Runごとにほぼ一定の值をとる。乙のて とは、砂堆の発達期・砂堆の安定期によらず、砂堆の形状はほ

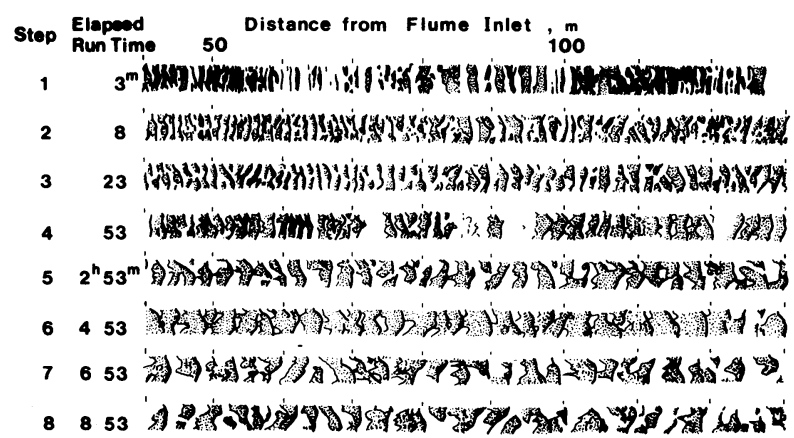

図-2 砂堆の形成過程 (流量 $1.5 \mathrm{~m}^{3} / \mathrm{sec}$ 、勾配 1/1000)

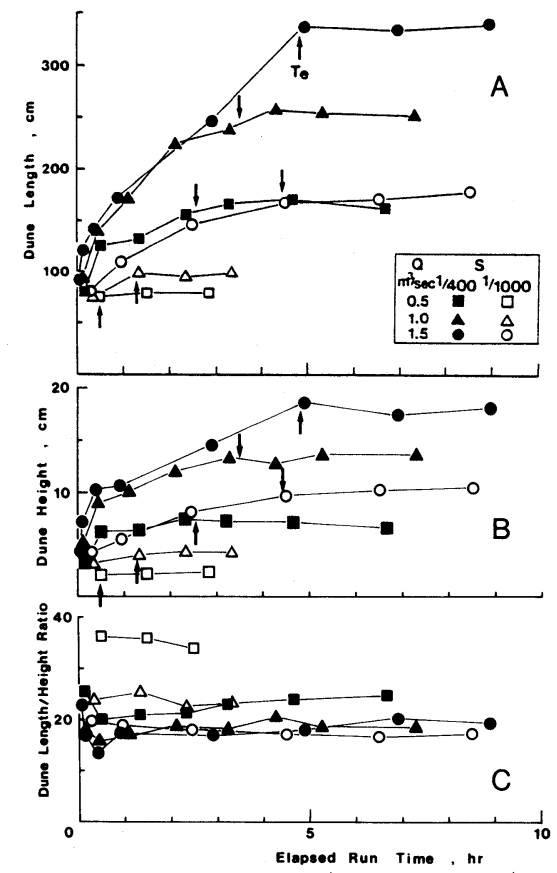

図 -3 砂堆の形状変化 $\left(T_{e}\right.$ : 安定化時間 $)$ 
ぼ相似形を保ったまま大きくなることを意味 している。

Case 2 の条件下においてす、砂堆の発達 が浮遊砂の濃度変化に強く関与していること が明らかになった。つまり、浮遊砂の濃度は 砂堆の発達期に大きく、砂堆の形状が定常に 達したあとの砂堆の安定期には小さいことが 判明した。砂堆の発達期と安定期とでなぜ浮 遊砂濃度が違うのかを、先ず図ー4 亿示す模 式図によって定性的に記載する。乙の図は水 路側壁のガラス板ごしに観察した結果で、砂 堆の発達期と安定期に、それぞれ卓越する流
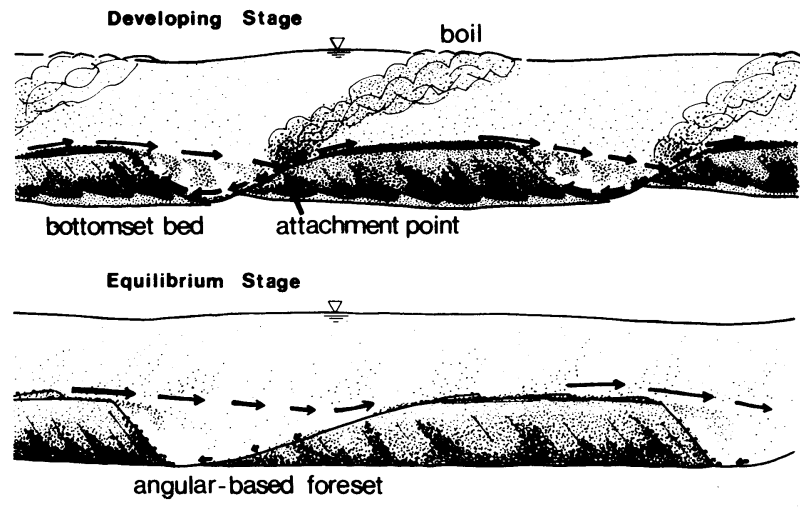

図-4 砂堆の発達期と安定期における流砂形態と堆積構造 砂形態と砂堆の堆積構造を模式的に示したも のである。三次元的な事象を二次元平面であらわすのは勿論無理なととではあるが、それを差し引いても、 砂堆の発達段階によってはっきりとした差違が認められる。

砂堆の発達期の、特に後半部には、砂堆の前縁からはく離した強い乱れが、前方の砂堆の再付着点に間欠 的に強くぶつかるという流れが卓越している。再付着点に強くぶつかった流れによって、ての付近の砂砼は 吹き払われ、砂堆の表面はまるでとけるように侵食されて著しく低下する。同時に乱れが強くぶつかった時 に、側方にねじれながら強く渦をまいて上昇する乱れが発生して、多量の砂が上昇するての強い乱れにとり てまれて上方に舞い上がっていくのが観察される。水面ではての上昇流はボイルとなって広がり、砂を多量 に含んだ黒々としたボイルが、ほぼ定位置に頻発している。このボイルは時に水面に音をたてて出現するほ ど強いことがある。再付着点付近で侵食された砂碟の大部分は、砂堆表面を高濃度で掃流されたのち砂堆の 前縁で崩れ落ちて堆積する。このため、砂堆の流下速度はこの時期に速く、砂堆背面での侵食と砂堆前面で の堆積が同時に進行する。乙の時の砂堆のトラフの形は、おわんの底のように上に丸みを帯びた形であるて とが特徵である。再付着点にぶつかった強い流れと、さらに、トラフ底にそった逆流とによってトラフはど んどん侵食されて低下し、砂堆の波高が増していく。水路内から水を排水した時には、ての部分が最後まで 水のたまった丸い深掘れとなって点在している(図一 2 )。

それに対して、砂堆の安定期には、再付着点にぶつかる強い乱れはほとんどなくなり、従って、トラフ底 での逆流も弱く、砂堆の前面では崩れ落ちてきた砂碟が水中安息角で堆積してトラフ底と急傾斜で接してい る。砂堆の発達期とはトラフの形状そのあのが違っている。この時期には、浮遊は砂堆表面を掃流される掃 流砂層から漸移的に生じており、特に砂が激しく舞い上がるという地点はほとんど認められなくなる。

上述した砂堆の発達期と安定期に打ける浮遊砂濃度と流水の乱れの違いは、図一 5 打よび図一 6 に明らか である。まず、図ー 5 は砂堆の発達期の変化であり、3 高度から採水した浮遊砂濃度の時間的な变化(図一 $5 \mathrm{~A}$ ) を、時空間的なアイソプレス（図一 5 B ）にして示す。砂堆の発達期には、浮遊砂濃度が全体に高い。 その上時間的に大きく変動していることに注目される。ての変動てそが、砂堆の形状と対応した浮遊砂濃度 の空間的な分布を反映したものである。Step 5 の範囲で砂床高の極小值が急減しているが、これは砂堆のト ラフが深く掘り込まれて、砂堆の波高が急増しているととを示す。ての範囲で浮遊砂濃度が高く、しかも時 間的にあ大きく変動していることは、砂堆の再付着点上から発生する強い上昇流が多量の砂を浮遊させてい るという観測結果を強く支持している。

とてろが、砂堆の安定期においては、浮遊砂濃度の変化の様子は一変する。図一 $6 \mathrm{~A}, \mathrm{~B}$ 示すように、砂堆 の安定期においては、流量や勾配は一定しているにもかかわらず、しかも波長の大きい砂堆が次々に流下し ているにあかかわらず、浮遊砂の濃度は小さく、さらに空間的な濃度のばらつきもほとんど認められない。 


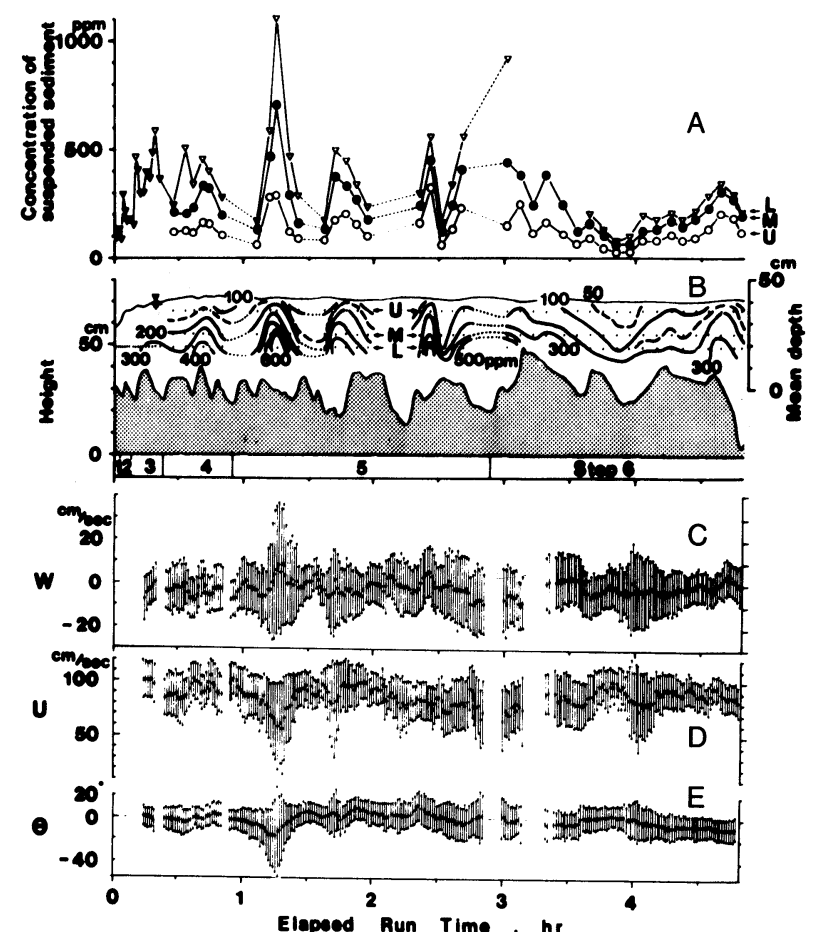

図一 5 砂堆の発達期に打ける浮遊砂濃度と流水の乱れの変化

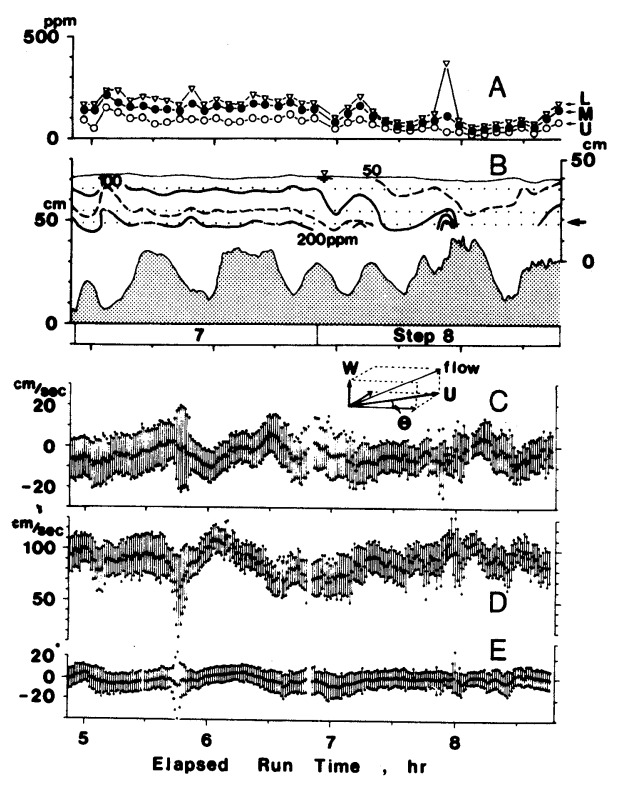

図一 6 砂堆の安定期における変化

（流量 $1.5 \mathrm{~m}^{3} / \mathrm{sec}$, 勾配 $1 / 1000 \mathrm{~L}, \mathrm{M}, \mathrm{U}$ は採水高度を、図一 $6 \mathrm{~B}$ 右の矢印は超音波流速計のセンサ一中心高を示す。）

一方、図一 5 C ，D，E および図一 6 C , D , E は超音波流速計による乱れの計測結果を示す。流れの三次元 成分のうち、上向きの速度成分 $(\mathrm{W})$ と、 $\mathrm{X}-\mathrm{Y}$ 平面上での合成流速 $(\mathrm{U})$ 、执よ゙それが水路の流下方向 $(\mathrm{X}$ 軸）とのなす角度を $\theta$ として、それぞれの一分間の平均值と、各成分の変動幅を平均值からの標準偏差の幅 $( \pm 2 \sigma)$ で示したあのである。速度成分 UとWの平均值は、従来からいわれているように ${ }^{10)}$ 砂堆の形状に 対応して增加・減少する。乙のてとは、砂堆の発達期 (図－5 C , D )、安定期 (図－6 C , D ) を問わず共 通している。たとえば、Uについてみると、砂堆の背面上では、流水断面積が小さくなるわけであるから、 流れは加速されて平均値は大きくなる。トラフ上ではすべてがその逆である。

砂堆の発達期と安定期で最も根本的な流れの違いは、乱れの変動幅が違うという点にある。砂堆の発達期 には、乱れの変動幅そのものが大きく変化している。通水後 1 時間 15 分前後をみると、Wの平均値が上向き に最大となった時、Wの変動幅は大きくなっている。ての位置がちょうど砂堆の再付着点上にあたっており、 ての時Uは最少となり、逆住変動幅は最大となっている。乙てで特に注目されることは、Uの角度 $\theta$ の平均 值が水路の流下方向からずれて向きを変え、しかる大きく変動しているてとである。てのてとは、まさに激 しく渦を巻きながら回転する渦の存在を示すむので、再付着点上に強い上昇流があることをてれらの測定結 果は裏付けている。それに対して、砂堆の安定期には流水の乱れの変動幅は小さくなって、しかも、ほぼ同 じような幅で変動している。

\section{5. 安定化時間に関する考察}

砂堆の安定化時間が何によって決定されるかについて若干の考察を行い、砂床河川において洪水の増水期 は、常に砂堆の発達期にあるととを示す。まず、図一 7 は、水深と砂堆の波長との関係をみたものである。 砂堆の波長が水深によって一義的に決定されるという考えが、一般には広く受け入れられている。とてろが、 両者の関係はかなりばらつき、ほぼ水深が同じであってあ、勾配の急な流れの方が波長の大きい砂堆が形成 
されている。とのととは、砂堆の波長がストリーム・パワー（＝rq S ) と良い対応関係を持つととを示唆す る。河床の凹凸の程度、すなわち砂堆による形状抵抗が大きければ大きいほど、流水はエネルギーをより多 く消費するわけであるから、図ー8 8 および図ー9 の関係はもっともな関係であるといえよう。砂堆の安定化 時間もやはりストリーム・パワーと良い対応関係を持つ（図ー10)。砂堆の形状が大きくなるゆえに、その

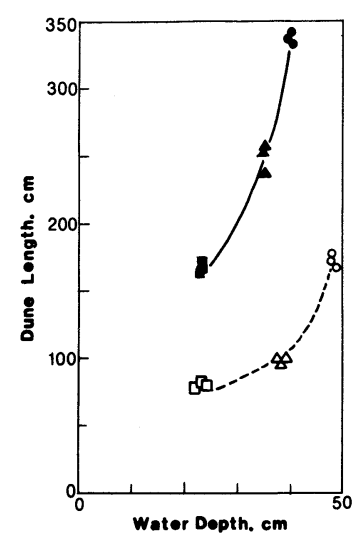

図-7 水深と砂堆波長の関係

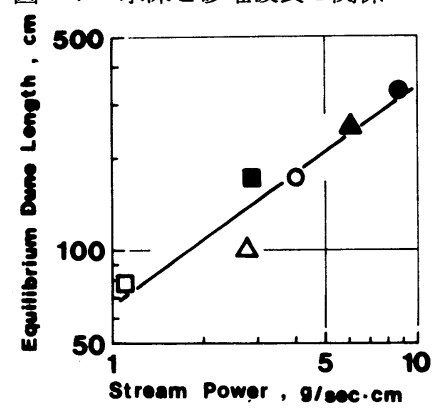
形状が安定するのには時間がかかるというととである。野外の河川での砂堆の 安定化時間を、図一10から直接算定するにはまだ多くの検討課題を残している。 しかし、河川の一地点で考えると、ストリーム・パワーの増加は流量の增加に よってもたらされる。従って、図一10の関係は洪水時に流量が増せば増すほど 砂堆の形状が安定するのにはより長い時間がかかるというととを意味するあの 之解釈される。洪水になると流れが強くなるから、河床はたちまちのうちにそ の流机対応して安定するというように従来は考えられがちであった。しかし、 図一10の関係はそれとは逆であるとと、すなわち、流量が増えれば増えるほど、 砂堆の形状はその流量変化になかなか追いつけないで常に発達の途中にあるこ とを示している。
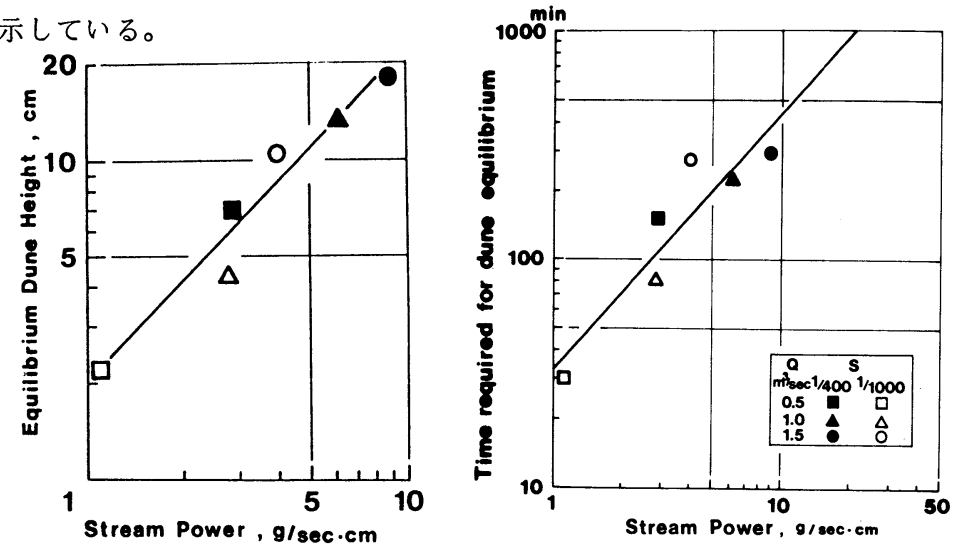

ストリーム・パワーと砂堆の波長 $($ 図 -8$)$ 、砂堆の波高 $($ 図一 9 ) 拈よび砂堆の安定化時間 $($ 図一10) の関係

\section{6. おわりに}

以上のととから、砂床河川で増水期に浮遊砂濃度が高い理由は、増水期は常に砂堆の発達期にあるためで あると結論される。流量変化が急激に生じる河川では、洪水時の浮遊運搬を、河床形の発達が強く支配して いるといえょう。利根川や江戸川などの洪水で、増水の時には黒々としたボイルが盛んに発生しているのに 対して、ひとたび減水が始まると水面はずっと抢となくなってしまい、ボイルも弱くなってほとんどみら れなくなるということをたびたび観察したが、増水期と減水期とでなぜてのように水面の乱れに差があるの かは今まで不明であった。しかし、てのような表面流況の変化は、実験において観察されたてととよく類似 している。増水期の強いボイルの存在は、増水期に砂堆が激しく発達・移動しているとと、そしててのよう な砂堆の変形が流れの大規模な乱流構造に影響を与えて多量の砂を浮遊させているてとを予想させる。

謝辞 本論をまとめるにあたっては、筑波大学地球科学系井口正男教授に終始で指導いただいた。水理実験センターの小島豊盛・ 飯島英夫両技官や、学生諸氏には実験をお手伝いいただいた。記して感謝いたします。

引用文献 1) 伊勢屋：第23回水理講演会論文集，1979 2 2）伊勢屋 : 筑波大学水理実験センター報告，6, 1982 3) ISEYA: Environmental Research Center Papers (Univ. Tsukuba), № 5, 1984 4) 池田 -伊勢屋 : 地形, 2, 1980 5) 高木他： 第26回水理講演会論文集, 1982 6）土屋 : 第26回年次学術講演会講演集, 1971 7） Simons \& Richardson, USGS WaterSupply Irri. Paper, 1498-E, 1962 8) Allen: Sedimentology，20, 1973 9）伊勢屋：地理評, 55, 1982 10) Raudkivi : Loose boundary hydraulics, Pergamon Press, 1967 11) たとえば、Yalin : Mechanics of sediment transport, Pergamon Press, 1972 